Journal of Engineering and Applied Sciences 14 (Special Issue 4): 7277-7283, 2019

ISSN: 1816-949X

(C) Medwell Journals, 2019

\title{
Mollusca Diversity in Aquatic Ecosystem
}

Sadiq Kadhum Alzurfi, Jaafar B. Algburi, Murtdha Mohammed Taher, Laith Hemed Alhachami and Karrar A. Zwain

Department of Ecology, Faculty of Science, University of Kufa, Kufa, Iraq

sadiqk.alzurfi@uokufa.edu.iq

\begin{abstract}
Study research aims to study freshwater biodiversity of Mollusca at Euphrates River, Iraq. Four sites were chosen during a period of 6 months (from December, 2016 to May, 2017). Physiochemical properties of Euphrates River were measured, e.g. (water temperature, pH, Electrical Conductivity (EC), Total Dissolved Solid (TDS), salinity, alkalinity, total hardness, Calcium ion $\left(\mathrm{Ca}^{2+}\right)$, Magnesium ion $\left(\mathrm{Mg}^{2+}\right)$, dissolved oxygen, biological oxygen demand and chloride) total organic carbon and organic matter in sediments. Eight species were classified, the dominate species were found to be Corbicula fluminea and Melanopsis nodosa while Pseudodontopsis euphraticus was showed to be at January, 2017. Shannon's diversity index recorded higher value in site 2 at near Imam Ali bridge during January, 2017. Pielou's evenness was recorded the highest record in site 4 (under the Cement Plant Bridge) during February and Margalef index in site 1 (North of Imam Ali bridge about $1 \mathrm{~km}$ ) during December, 2016 about (2.46). Some of the physicochemical properties had positive or negative relationship with the numbers of species, others had a reversed relation.
\end{abstract}

Key words: Ecosystem, biodiversity, mollusca, Euphrates, Iraq, water temperature

\section{INTRODUCTION}

Invertebrates play a prominent role in the environment. Invertebrates are an important part of the food chain in the aquatic environment and have a significant role in the aquatic ecosystem balance (Cock et al., 2011), despite the damage invertebrate may cause; these animals have many benefits to their environments. They are used as food sources for humans in many countries as well as being a stable food for fish and birds as they are rich in protein (Chapman and Wang, 2001). Gastropoda is the most important species belonging to this division. The members of these species, especially, snails are common element in aquatic environments (Johnson, 2009) and the assessment of their presence in these waters leads us to the assessment of the nature of the ecosystem (Aldridge, 1983; Dillon, 2000). It is the largest group consisting of approximately 30,000 marine snail species, 30,000 terrestrial snail species and 5,000 freshwater snail species.

Taxonomic expertise is a basic foundation for estimation of global biodiversity and formulation of policy on conservation of biological diversity. Snails act as primary consumers eating diatoms, algae and plants and thus are important aspects of aquatic primary production. Many snails are also, nonspecific feeders acting as detritivores (Dillon, 2000). Although, snails are important aspects of freshwater ecology, reliable up-to-date data concerning the distribution of freshwater snails. They are absent for most North America and South Dakota, in particular. Absence of data on freshwater mollusk species are conservation concern, since, worldwide non-marine mollusks may be one of the most threatened groups of organisms (Lydeard et al., 2004).

Freshwater snails can be found living at the bottoms of the largest lakes and rivers as well as the smallest streams and ponds. Some species have been recorded at depths of over 100 feet (Johnson, 2009).

This study will help future research in conservation biology that may improve our current understanding of the factors affecting freshwater gastropod fauna in Iraq and assist in developing effective eradication and containment schemes to the benefit of agriculture and public health.

Study area: Euphrates River in the Kifl city is divided into two branches of Abbasiya and Kufa Rivers which runs from the Kifl city to Diwaniyah and has a total length of about $36 \mathrm{~km}$ and a flow of about $375 \mathrm{~m}^{3} / \mathrm{sec}$ with an actual capacity $552 \mathrm{~m}^{3} / \mathrm{sec}$.

To attain the study aim, four sites were chosen along the Kufa River. They have been identified as study sites using a (GPS) (Fig. 1 and 2):

Corresponding Author: Sadiq Kadhum Alzurfi, Department of Ecology, Faculty of Science, University of Kufa, Kufa, Iraq, sadiqk.alzurfi@uokufa.edu.iq 


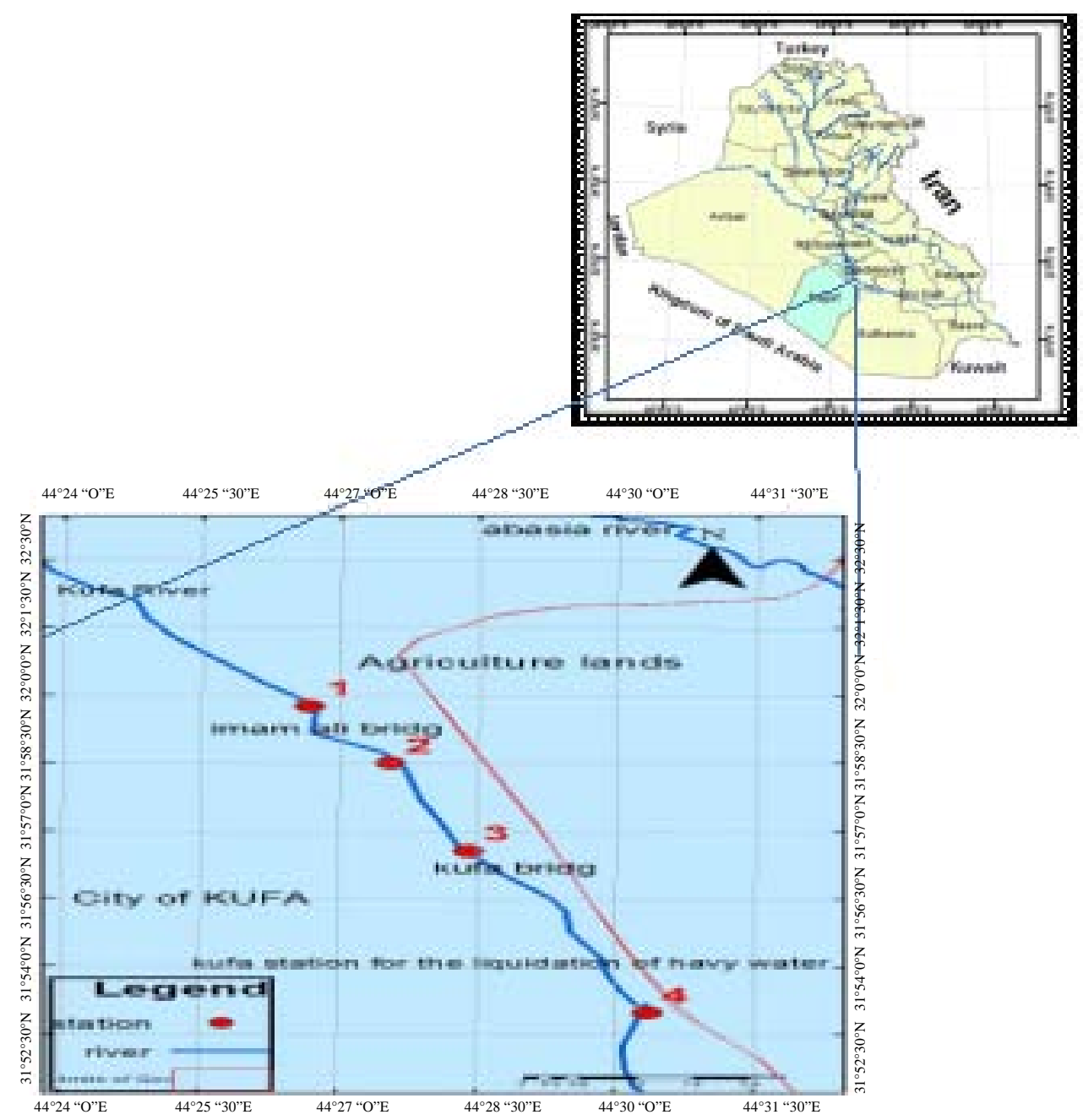

Fig. 1: Base map of the study area

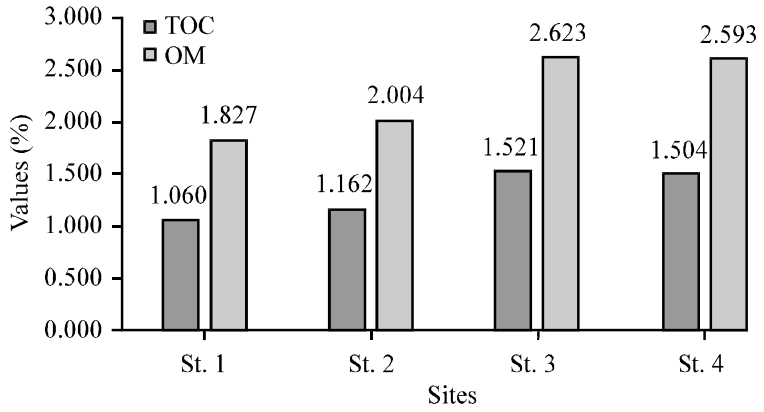

Fig. 2: Means of total organic carbon and organic material in study sites during period study

- First site (St. 1): located north of Imam Ali Bridge about $1 \mathrm{~km}$. This site is characterized by the absence of industrial activity except agricultural activities

- Second site (St. 2): located near Imam Ali Bridge
- Third site (St. 3): located at $1 \mathrm{~km}$ away from the second site

- Fourth site (St. 4): located $4 \mathrm{~km}$ away from the third site under the Cement Plant Bridge

\section{MATERIALS AND METHODS}

This study is conducted from December, 2016 to May 2017. Analysis of samples was conducted in Laboratory of Ecology Department, Faculty of Science, Kufa University. The water samples were collected from a depth of $20 \mathrm{~cm}$ in each site by polyethylene container reserve in an ice box and transported to laboratory. Water temperature was measured by thermometer ranging $\left(0-100^{\circ} \mathrm{C}, \mathrm{UK}\right)$ while the electrical conductivity, TDS, salinity and $\mathrm{pH}$ were measured by portable multi meter (German, WTW). Azide modification method of Winkler 
(APHA, 2003) was used to determine dissolved oxygen after fixing in field. Turbidity factor was measured by portable turbid meter (Lovibond, Germany) after calibration of meter by different solutions $(0.01,10$, 1000). Total alkalinity was measured according to Lind (1979), total hardness, $\mathrm{Ca}^{2+}$ and $\mathrm{Mg}^{2+}$ hardness according to (APHA, 2003). Snail samples were collected using $(1 \times 1)$ $\mathrm{m}$ quadrant along the water body of Euphrates River. Each collection was repeated three times. All collected snails were identified into species level and the number of each genus was recorded for biodiversity indices measurement. Some taxonomic keys were used such as (Ahmed, 1975; Harrold and Guralnick, 2010).

\section{Biodiversity indexes}

Shannon index of diversity (H'): Calculation of equation (Shannon and Weaver, 1949).

Margalef index: It is denoted by ' $d$ '. This method of comparing species richness between different samples collected from various habitats is easy (Margalef, 1969).

Species evenness index: The species evenness index is calculated from Pielou's equation (1975).

Statistical analysis: Simple linear correlation coefficient and two-way ANOVA test were used for further statistical analyses. The value $\mathrm{p}<0.05$ was considered statistically significant. All statistics were conducted by Excel 2007.

\section{RESULTS AND DISCUSSION}

Eight species were classified during the study period and recorded Corbicula fluminea and Melanopsis nodosa with more significant appearance in all months while Pseudodontopsis euphraticus appeared only in January, 2017 (Table 1). Table 2 shows the number of species in the study sites and the values of environmental indices of plant diversity. The first site recorded by McCreesh et al. (2014). Variation of locations of temperatures may come from difference of sample collection times. Highest number of species compared with the other sites. The second site recorded the highest diversity values (1.13) in January, 2017 and highest value of richness index which reached (2.46) in site 1 during December 2016.

The rapid decline in diversity and abundance of freshwater snails may be to the variety of human degradations of their natural habitats. The most prominent impacts could include: dams and impoundments, channelization and dredging, sedimentation and channel instability and water pollution (Johnson, 2009). Agostinho et al. (2004) showed that the large variation, frequency and duration of change in water level were all responsible for the high biodiversity. On the other hand, increasing water depth may lead to the reduction of necessary nutrients for growth and spread of aquatic organisms. Nutrients are related to the biological diversity of the aquatic organisms and water surface that has poor nutrients yield few species. The average nutrient surface is located in the middle and is more diverse than aquatic life. The appearance of some species and disappearance of others in some sites and persistence of the presence of certain species in all sites during study period cannot be attributed to a particular cause, except to the overlap of a variety of environmental factors (Madoni, 1991; Salvado et al., 2001).

Temperature is one of most important factors in the aquatic environment. Its decline leads to inhibition of many vital functions of aquatic organisms such as growth, reproduction, movement and nutrition. Stewart and Garcia (2002). Water temperature ranged 9.3-28. $1^{\circ} \mathrm{C}$ at site 1 and 2 during December, 2016 and May, 2017, respectively (Table 3 ). The current study showed

\begin{tabular}{|c|c|c|c|c|c|c|c|c|c|c|c|c|c|c|c|c|c|c|c|c|c|c|c|c|}
\hline \multirow[b]{2}{*}{ Species } & \multicolumn{4}{|c|}{ December, 2016} & \multicolumn{4}{|c|}{ January, 2017} & \multicolumn{4}{|c|}{ February, 2017} & \multicolumn{4}{|c|}{ March, 2017} & \multicolumn{4}{|c|}{ April, 2017} & \multicolumn{4}{|c|}{ May, 2017} \\
\hline & $\mathrm{S} 1$ & $\mathrm{~S} 2$ & S3 & $\mathrm{S} 4$ & $\mathrm{~S} 1$ & $\mathrm{~S} 2$ & $\mathrm{~S} 3$ & $\mathrm{~S} 4$ & $\mathrm{~S} 1$ & $\mathrm{~S} 2$ & S3 & $\mathrm{S} 4$ & $\mathrm{~S} 1$ & $\mathrm{~S} 2$ & $\mathrm{~S} 3$ & $\mathrm{~S} 4$ & $\mathrm{~S} 1$ & $\mathrm{~S} 2$ & S3 & $\mathrm{S} 4$ & $\mathrm{~S} 1$ & $\mathrm{~S} 2$ & S3 & $\mathrm{S} 4$ \\
\hline $\begin{array}{l}\text { Pseudodontopsis } \\
\text { euphratic us }\end{array}$ & 0 & 0 & 0 & 0 & 0 & 1 & 0 & 0 & 0 & 0 & 0 & 0 & 0 & 0 & 0 & 0 & 0 & 0 & 0 & 0 & 0 & 0 & 0 & 0 \\
\hline $\begin{array}{l}\text { Melonoides } \\
\text { tuberculata }\end{array}$ & 2 & 0 & 0 & 0 & 0 & 0 & 0 & 0 & 1 & 4 & 0 & 2 & 82 & 0 & 0 & 0 & 45 & 9 & 0 & 0 & 9 & 0 & 0 & 0 \\
\hline $\begin{array}{l}\text { Viviparus } \\
\text { bengalensis }\end{array}$ & 0 & 0 & 0 & 0 & 13 & 4 & 3 & 4 & 10 & 9 & 2 & 0 & 20 & 11 & 29 & 7 & 9 & 0 & 7 & 3 & 8 & 4 & 4 & 5 \\
\hline Unio tigrads & 1 & 0 & 8 & 0 & 0 & 0 & 2 & 0 & 0 & 1 & 0 & 0 & 0 & 6 & 0 & 0 & 1 & 1 & 0 & 0 & 5 & 0 & 2 & 0 \\
\hline $\begin{array}{l}\text { Monacha } \\
\text { obstructa }\end{array}$ & 0 & 0 & 0 & 0 & 1 & 0 & 0 & 0 & 0 & 0 & 0 & 0 & 0 & 0 & 0 & 0 & 0 & 0 & 0 & 0 & 0 & 2 & 0 & 0 \\
\hline $\begin{array}{l}\text { Corbicula } \\
\text { fluminea }\end{array}$ & 10 & 8 & 15 & 5 & 12 & 12 & 6 & 4 & 8 & 31 & 0 & 2 & 33 & 41 & 0 & 0 & 30 & 22 & 5 & 0 & 29 & 6 & 0 & 0 \\
\hline $\begin{array}{l}\text { Melanopsis } \\
\text { nodosa }\end{array}$ & 28 & 0 & 13 & 0 & 10 & 6 & 41 & 8 & 0 & 0 & 3 & 0 & 9 & 3 & 0 & 0 & 13 & 10 & 1 & 0 & 6 & 0 & 0 & 0 \\
\hline $\begin{array}{l}\text { Theodoxus } \\
\text { jordoni }\end{array}$ & 1 & 0 & 0 & 0 & 13 & 0 & 0 & 0 & 0 & 0 & 0 & 0 & 0 & 0 & 0 & 0 & 0 & 0 & 0 & 0 & 0 & 0 & 0 & 0 \\
\hline
\end{tabular}


Table 2: Environment indices of snail biodiversity in sites through study period $(\mathrm{S}=$ Species number, $\mathrm{N}=\mathrm{Total}$ number, $\mathrm{H}=\mathrm{Shannon}$ 's diversity index, H.max $=$ maximum possible value of $\mathrm{H}, \mathrm{E}=$ Pielou's evenness, $\mathrm{D}=$ Margalef index $)$

\begin{tabular}{|c|c|c|c|c|c|c|}
\hline Months/Sites & $\mathrm{S}$ & $\mathrm{N}$ & $\mathrm{H}$ & H.max & $\mathrm{E}$ & $\mathrm{D}$ \\
\hline \multicolumn{7}{|c|}{ December 2016} \\
\hline St. 1 & 5 & 42 & 0.85 & 1.61 & 0.53 & 2.46 \\
\hline St. 2 & 1 & 8 & 0.34 & 0.00 & 0.00 & 0.00 \\
\hline St. 3 & 3 & 36 & 1.07 & 1.10 & 0.97 & 1.29 \\
\hline St. 4 & 1 & 5 & 0.59 & 0.00 & 0.00 & 0.00 \\
\hline \multicolumn{7}{|l|}{ January 2017} \\
\hline St. 1 & 5 & 49 & 1.10 & 1.61 & 0.68 & 2.37 \\
\hline St. 2 & 4 & 23 & 1.13 & 1.39 & 0.82 & 2.20 \\
\hline St. 3 & 4 & 52 & 0.73 & 1.39 & 0.52 & 1.75 \\
\hline St. 4 & 3 & 16 & 1.04 & 1.10 & 0.95 & 1.66 \\
\hline \multicolumn{7}{|l|}{ February } \\
\hline St. 1 & 3 & 19 & 0.86 & 1.10 & 0.78 & 1.56 \\
\hline St. 2 & 4 & 45 & 0.88 & 1.39 & 0.63 & 1.81 \\
\hline St. 3 & 2 & 5 & 0.67 & 0.69 & 0.97 & 1.43 \\
\hline St. 4 & 2 & 4 & 0.69 & 0.69 & 1.00 & 1.66 \\
\hline \multicolumn{7}{|l|}{ March } \\
\hline St. 1 & 4 & 144 & 1.11 & 1.39 & 0.80 & 1.39 \\
\hline St. 2 & 4 & 61 & 0.95 & 1.39 & 0.69 & 1.68 \\
\hline St. 3 & 1 & 29 & 0.00 & 0.00 & 0.00 & 0.00 \\
\hline St. 4 & 1 & 7 & 0.00 & 0.00 & 0.00 & 0.00 \\
\hline \multicolumn{7}{|l|}{ April } \\
\hline St. 1 & 5 & 98 & 1.21 & 1.61 & 0.75 & 2.01 \\
\hline St. 2 & 4 & 42 & 1.10 & 1.39 & 0.79 & 1.85 \\
\hline St. 3 & 3 & 13 & 0.90 & 1.10 & 0.82 & 1.80 \\
\hline St. 4 & 2 & 8 & 0.66 & 0.69 & 0.95 & 1.11 \\
\hline \multicolumn{7}{|l|}{ May } \\
\hline St. 1 & 5 & 57 & 1.15 & 1.61 & 0.71 & 2.28 \\
\hline St. 2 & 3 & 14 & 1.08 & 1.10 & 0.98 & 1.75 \\
\hline St. 3 & 2 & 6 & 0.64 & 0.69 & 0.92 & 1.29 \\
\hline St. 4 & 1 & 5 & 0.00 & 0.00 & 0.00 & 0.00 \\
\hline
\end{tabular}

Table 3: Mean and standard deviation of monthly variations of water parameters in study site of Kufa River

\begin{tabular}{|c|c|c|c|c|c|c|c|}
\hline$\underline{\text { Parameters/Units }}$ & December 2016 & January 2017 & February & March & April & May & $\mathrm{p}$-values \\
\hline WT $\left({ }^{\circ} \mathrm{C}\right)$ & $11.2 \pm 1.6$ & $15.9 \pm 1.6$ & $19.1 \pm 0.9$ & $20.8 \pm 1.5$ & $24.5 \pm 1.3$ & $27.5 \pm 0.6$ & $4.1^{*} 10^{-6}$ \\
\hline $\mathrm{pH}$ & $7.96 \pm 0.2$ & $8.08 \pm 0.2$ & $8.05 \pm 0.4$ & $7.56 \pm 0.4$ & $7.49 \pm 0.6$ & $7.36 \pm 0.5$ & $6.8^{*} 10^{-21}$ \\
\hline $\mathrm{EC}(\mu \mathrm{sec} / \mathrm{cm})$ & $1011 \pm 110$ & $1090 \pm 137$ & $1121 \pm 153$ & $1338 \pm 114$ & $996 \pm 38$ & $1047 \pm 36$ & $3.3^{*} 10^{-7}$ \\
\hline $\mathrm{TDS}(\mathrm{mg} / \mathrm{L})$ & $577 \pm 107$ & $620 \pm 94$ & $550 \pm 56$ & $883 \pm 75$ & $656 \pm 21$ & $691 \pm 24$ & 0.0001 \\
\hline Sal. (ppt.) & $0.65 \pm 0.07$ & $0.70 \pm 0.09$ & $0.72 \pm 0.1$ & $0.86 \pm 0.07$ & $0.64 \pm 0.02$ & $0.67 \pm 0.02$ & $3.3^{*} 10^{-7}$ \\
\hline $\mathrm{DO}(\mathrm{mg} / \mathrm{L})$ & $8.1 \pm 0.7$ & $9.3 \pm 0.8$ & $9.1 \pm 0.9$ & $9.6 \pm 1$ & $8.7 \pm 1$ & $8.5 \pm 0.1$ & $2.2 * 10^{-28}$ \\
\hline $\mathrm{BOD}(\mathrm{mg} / \mathrm{L})$ & $2.2 \pm 0.61$ & $2.3 \pm 0.18$ & $2.4 \pm 0.49$ & $2.3 \pm 0.79$ & $2.5 \pm 0.67$ & $3.2 \pm 0.54$ & $1.3^{*} 10^{-23}$ \\
\hline AlK. (mg/L) & $157 \pm 77$ & $135 \pm 41$ & $130 \pm 13$ & $121 \pm 2$ & $144 \pm 4$ & $147 \pm 9$ & $1.2 * 10^{-30}$ \\
\hline $\mathrm{TH}(\mathrm{mg} / \mathrm{L})$ & $482 \pm 243$ & $478 \pm 33$ & $360 \pm 93$ & $627 \pm 36$ & $403 \pm 50$ & $427 \pm 19$ & $1.8^{*} 10^{-7}$ \\
\hline $\mathrm{Ca}^{++}(\mathrm{mg} / \mathrm{L})$ & $262 \pm 224$ & $171 \pm 113$ & $119 \pm 29$ & $88 \pm 44$ & $77 \pm 14$ & $75 \pm 17$ & $3.3^{*} 10^{-36}$ \\
\hline $\mathrm{Mg}^{2+}(\mathrm{mg} / \mathrm{L})$ & $82 \pm 64$ & $120 \pm 57$ & $33 \pm 29$ & $131 \pm 18$ & $79 \pm 9$ & $85 \pm 6$ & $1.2 * 10^{-16}$ \\
\hline $\mathrm{Cl}^{-}(\mathrm{mg} / \mathrm{L})$ & $181 \pm 98$ & $503 \pm 64$ & $246 \pm 56$ & $253 \pm 62$ & $267 \pm 67$ & $280 \pm 73$ & $3.3^{*} 10^{-52}$ \\
\hline
\end{tabular}

increasing density and diversity of snails with low water temperatures due to the amount of thermal effect of sun Table 3 shows the monthly variations of $\mathrm{pH}$ values in study sites which recorded the average (6.89-8.52) in site 3 and 1 during April and February, 2017, respectively.

Wetzel (2001) indicated that the $\mathrm{pH}$ value is controlled by the relationship between the concentration of Hydrogen ion $\left(\mathrm{H}^{+}\right)$released from the carbonic acid and Hydroxyl radical $\left(\mathrm{OH}^{+}\right)$resulting from bicarbonate decomposition. The narrow range of $\mathrm{pH}$ in river water may also be due to buffer capacity where it resists the variations in $\mathrm{pH}$ (Harris, 2007). Therefore, the $\mathrm{pH}$ values were within a narrow range and did not differ significantly as was observed in several studies (Hassan,
2004; Al-Laami et al., 1996; Hassan, 1997, AbdulhamzalAl-Fanharawi and ShanonIbrahim, 2014; Alzurfi et al., 2018). Electrical conductivity is an indicator of water soluble salts and is closely related to total soluble solids (Wetzel, 2001). Values recorded electrical conductivity between (859-1485) $\mu \mathrm{sec} / \mathrm{cm}$ in site 1 during December 2016 and March, 2017, respectively, (Table 3) and the salinity recorded values between (0.5-1) ppt. in site 1 during December 2016 and March, 2017, respectively, (Table 3 ). The highest values of TDS in river water were recorded during March, 2017 (980 mg/L) in site 1 and decreased during April (443 mg/L) in site 1 during December, 2016 (Table 3 ) as a result of rising water levels and the influence of mitigation factor (Al-Mussawi et al., 1995 ) or the influence of agricultural and industrial 
Table 4: Coefficient of correlation between number of snail and physico-chemical parameters during study period

\begin{tabular}{lr}
\hline Parameters & $\mathrm{R}$ \\
\hline Water temperature & 0.12 \\
pH & -0.32 \\
EC & 0.70 \\
TDS & 0.84 \\
Salinity & 0.70 \\
DO & 0.68 \\
BOD & -0.35 \\
TH & 0.79 \\
$\mathrm{Ca}^{2+}$ & -0.33 \\
$\mathrm{Mg}^{2+}$ & 0.75 \\
$\mathrm{Alkalinity}_{\mathrm{Cl}}$ & -0.59 \\
TOC & 0.13 \\
OM & -0.86 \\
& -0.86 \\
\hline
\end{tabular}

activity. Hutchinson and Edmondson (1957) or as a result of the flow of brackish water from the adjacent river dams (Al-Lami and Al-Jaberi, 2002). This is what has been agreed with other studies (Hassan, 1997, 2004; Al-Zurfi et al., 2010; Alzurfi et al., 2018). It was concluded that there is a direct relationship between TDS and number of species (0.84) (Table 4). Table 3 shows the monthly variations of dissolved oxygen in the study sites where the values were $5.6-12.1 \mathrm{mg} / \mathrm{L}$ in site 2 and site 1 during March and May, respectively. Dissolved oxygen in water is essential in the metabolic processes of all aquatic organisms (Wetzel, 2001). It is added to water from the atmosphere or as a result of photosynthesis of aquatic plants and phytoplankton (Wetzel and Linkens, 2000). It is also a determining factor for the growth of many aquatic organisms (Smith, 2004). The dissolved oxygen levels vary according to temperature variability (Al-Saadi et al., 1998) and the pressure and concentration of different ions in water (Wetzel and Linkens, 2000). It was observed a significant increase in dissolved oxygen values in most sites which may be due to good ventilation and continuous mixing in these sites and the density of phytoplankton and aquatic plants (Al-Lami and Al-Jaberi 2002; Hassan, 2004). Low dissolved oxygen values in site 2 may be due to low water level in March and degradation of organic matter (Thirupathaiah et al., 2012). Biological Oxygen Demand $\left(\mathrm{BOD}_{5}\right)$ refers to the amount of consumed oxygen in destroying organic matter added to water by microorganisms which negatively affects water quality (Weiner, 2000). $\mathrm{BOD}_{5}$ values were $(1.4-3.7) \mathrm{mg} / \mathrm{L}$ in site 3 and site 1 during December, 2016 and May, 2017, respectively (Table 3 ). The high values of $\mathrm{BOD}_{5}$ in site 1 may be due to direct disposal of organic waste into river (Al-Mussawi et al., 1995).

Total Hardness (TH) was found to be at the range between the lowest values during February, 2017 $(240 \mathrm{mg} / \mathrm{L})$ in Site 1 and the highest during December, $2016(840 \mathrm{mg} / \mathrm{L})$ in St. 2 (Table 3). The results show significant deference $(p<0.05)$ between months and negative correlation between $\mathrm{TH}$ and $\mathrm{BOD}_{5}$. The $\mathrm{TH}$ was responsible of total concentration of cat. Ions and a good indicator for the presence of some dissolved solid substances in water such as the $\mathrm{Ca}^{2+}$ and $\mathrm{Mg}^{2+}$ (Wurts and Durborow, 1992; Smith, 2004). The water of the Kufa River in the studied areas had intensive hardness according to Lind (1979). This may be due to drains from the nearby soils during the rainy season or due to the addition of industrial, human and agricultural waste to the river which is in consistent with several studies (Al-Lami et al., 1996, 1999; Al-Saadi et al., 2001; Hassan, 2004; Alzurfi et al., 2018). The study showed that $\mathrm{Ca}^{2+}$ concentrations were higher than $\mathrm{Mg}^{2+}$ in most months of the study. $\mathrm{Ca}^{2+}$ recorded a range of $43-596 \mathrm{mg} / \mathrm{L}$ in site 3 and 2 during March 2017 and December 2016, respectively (Table 3 ) and magnesium values were between $8-204 \mathrm{mg} / \mathrm{L}$ in site 4 and 2 during February and January, 2017 (Table 3).

Generally, $\mathrm{Ca}^{2+}$ was more than $\mathrm{Mg}^{2+}$ concentration in whole time of study due to converting to dissolved bicarbonate (Brown, 1980) which agrees with many studies about Iraqi water (Abdullah, 1989; Al et al., 2007).

Magnesium may increase as a result of drifting from nearby soils or flowing from factories and sewers, (Al-Lami et al., 2002) or may be due to the presence of phytoplankton in huge numbers (Maulood and Al-Mussawi etal., 1995) as confirmed by the study of (Al-Fatalawi, 2005) on the abundance of phytoplankton in the Euphrates River. According to the current study, there is a direct relationship between $\mathrm{Mg}^{2+}$ and the number of species which was $(0.75)$ (Table 4).

Total alkalinity is water content of carbonates, bicarbonates and hydroxides that affect temperature, increase organic matter degradation, increase concentration of $\mathrm{CO}_{2}$ and magnesium concentrations (Wetzel, 2001). Total alkalinity was recorded as (99-273) $\mathrm{mg} / \mathrm{L}$ in site 1 and 2 during January, 2017 and December, 2016, respectively (Table 3 ). The study showed that the river water had low alkalinity with only bicarbonate which is caused by increases conversion of non-dissolved calcium carbonate to bicarbonate (Weiner, 2000). This is consistent with researchers who conducted studies that this alkalinity is common in Iraqi water due to the availability of bicarbonate salts in water and near soils (Al-Lami et al., 1999; Al-Saadi et al., 1998). The levels of water have large effect on alkalinity (Smith, 2004). This study showed that chloride ion values in the study period ranged between $(97-1040) \mathrm{mg} / \mathrm{L}$ and the lowest value (97 mg/L) was in January, 2017 in site 1 while the highest value was $(1040 \mathrm{mg} / \mathrm{L})$ in the same site and month as shown in Table 3 which illustrates the effect of temperature on chloride concentration and amount drainage of waste in river. Figure 2 mean of total organic 
carbon and organic matter in study sites recorded higher values in site 3 and lower values in site 1 and negative correlation between number of species Table 4 may indicate that higher trophic status which is conducive to more proteinaceous shells (Burky et al., 1979), this is agree with Kajak and Dusoge (1989) study.

\section{CONCLUSION}

The current study concluded that there is a direct relationship between $\mathrm{Mg}^{2+}$ and number of snail species. Also, Corbicula fluminea and Melanopsis nodosa were recorded to have the most significant appearance in all months. Pseudodontopsis euphraticus appeared only in January with only one individual. Biodiversity was recorded to be the highest in site 1 due to the absence of activities that cause pollution. Also, the temperature has a significant effect on the appearance and distribution of snails.

\section{REFERENCES}

AL-Lami, A.A., T.I. Kassim and A.A. AL-Dylymei, 1999. A limnological study on Tigris River, Iraq. Sci. J. Iraqi Atomic Energy Commission, 1: 83-98.

APHA, 2003. Standard Methods for Examination of Water and Wastwater. 20th Edn., American Public Helth Association, Washington DC, USA.,.

AbdulhamzaAl-Fanharawi, A. and S. ShanonIbrahim, 2014. Environmental study of the benthic mollusks in Euphrates River at Samawa City, Iraq. Intl. J. Sci. Res., 3: 1955-1960.

Abdullah, M.S.D., 1989. Primary productivity for phytoplankton and environmental factors, which affect it in Shatt Al-Basrah canal. MSc Thesis, University of Basrah, ýBasrah, Iraq.

Agostinho, A.A., L.C. Gomes, S.M. Thomaz and N.S. Hahn, 2004. The Upper Parana River and its Floodplain: Main Characteristics and Perspectives for Management and Conservation. In: The Upper Parana River and its Floodplain: Physical Aspects, Ecology and Conservation, Thomaz, S.M., A.A. Augustinho and N.S. Hahn (Eds.). Backhuys Publishers, Leiden, Netherlands, pp: 381-393.

Ahmed, M.M., 1975. Systematic Study on Mollusca from Arabian Gulf and Shatt Al-Arab, Iraq. Arab Gulf Studies Center, Basra, Iraq, Pages: 78.

Al, R.S., I.J.M. Al-Shawi and F.J.M. Al-Imarah, 2007. Distribution of some chemical elements in the marsh lands of Southern Iraq after rehabilitation. Marsh Bull., 2: 11-17.

Al-Fatalawi, H.J.J., 2005. An environmental study of the Euphrates River between India and Al-Kifl, Iraq. Master Thesis, Babylon University, Babylon, Iraq.
Al-Laami, A.A., A.W. Sabri, T.I. Kassim and K.A. Rasheed, 1996. The ecological effects of Diyala River on Tigris river I. Limnology. J. Coll. Educ. Women Univ. Baghdad, 7: 84-92.

Al-Lami, A.A. and H.H. Al-Jaberi, 2002. Heavy metals in water, suspended particles and sediment of the upper-mid region of Tigris River, Iraq. Proceedings of the International Symposium on Environmental Pollution Control and Waste Management (EPCOWM'2002), January 7-10, 2002, Tunis, Tunisia, pp: 97-102.

Al-Mussawi, A.H.A., N.A. Hussien and Al-Aarajy, 1995. The influence of sewage discharge on the physico-chemical properties of some ecosystem at Basrah city, Iraq. Basrah J. Sci., 13: 135-148.

Al-Saadi, H.A., A.N. Al-Tamimi and A.A. Al-Ghafily, 1998. On the limnological features of Razzazah Lake, Iraq. Bas. J. Sci., 13: 41-48.

Al-Saadi, H.A., N.A. Sulaiman and A.M. Ismail, 2001. On some limnological characters of three lotic water system, middle of Iraq. Ibin Haitham J. Appl. Pure Sci., 2: 5-12.

Al-Zurfi, S.K., A.K. Mohammed and A.I. Shaheed, 2010. Study of some physical and chemical of Kufa River. J. Babylon Univ. Pure Appl. Sci., 18: 1399-1411.

Aldridge, D.W., 1983. Physiological Ecology of Freshwater Prosobranchs. In: The Mollusca: Ecology, Wilbur, K.M. and W.D. Russell-Hunter (Eds.). Academic Press, Cambridge, Massachusetts, USA., pp: 329-358.

Alzurfi, S.K.L., K. Alasadi and S.A. Alausawi, 2018. Assessment of water quality status of euphrates from Hindiya dam to Mishkab Regulator-Iraq. Res. J. Pharm. Technol., 11: 9-16.

Brown, A.L., 1980. Ecology of Freshwater. Heinemann Educational Books Ltd., Portsmouth, New Hampshire, Pages: 567.

Burky, A.J., M.A. Benjamin, D.M. Catalano and D.J. Hornbach, 1979. The ratio of calcareous and organic shell components of freshwater sphaeriid clams in relation to water hardness and trophic conditions. J. Molluscan Stud., 45: 312-321.

Chapman, P.M. and F. Wang, 2001. Assessing sediment contamination in estuaries. Environ. Toxicol. Chem., 20: 3-22.

Cock, M.J.W., J.C. Biesmeijer, R.J.C. Cannon, P.J. Gillespie et al., 2011. Climate change and invertebrate genetic resources for food and agriculture: State of knowledge, risks and opportunities. Food and Agriculture Organization, Rome, Italy.

Dillon, R.T., 2000. The Ecology of Freshwater Molluscs. Cambridge University Press, Cambridge, UK., ISBN:9781139426992, Pages: 509. 
Harris, D.C., 2007. Quantitative Chemical Analysis. 7th Edn., W.H. Freeman and Company, New York, USA., ISBN:9780716776949, Pages: 928.

Harrold, M.N. and R.P. Guralnick, 2010. A Field Guide to the Freshwater Mollusks of Colorado. 2nd Edn., Colorado Division of Wildlife, Denver, Colorado, Pages: 131.

Hassan, F.M., 1997. A limnological study on Hilla River. Al Mustansiriya J. Sci., 8: 22-30.

Hassan, F.M., 2004. Limnological features Diwanyia River, Iraq. Baghdad Sci. J., 1: 119-124.

Hutchinson, G.E. and Y.H. Edmondson, 1957. A Treatise on Limnology. Vol. 1, John Willey and Sons, New York, USA., ISBN-13: 9780471425700, Pages: 1015.

Johnson, P.D., 2009. Sustaining Americas aquatic biodiversity freshwater snail biodiversity and conservation. Master Thesis, College of Agriculture and Life Sciences, Virginia Polytechnic Institute and State University, Blacksburg, Virginia.

Kajak, Z. and K. Dusoge, 1989. Temporal and spatial diversity of trophy-indicators in a lowland dam reservoir. Ekologia Polska, 37: 211-233.

Lind, O. T., 1979. Handbook of Common Methods in Limnology. 2nd Edn., Mosby, Maryland Heights, Missouri, USA., ISBN:9780801630194, Pages: 199.

Lydeard, C., R.H. Cowie, W.F. Ponder, A.E. Bogan and P. Bouchet et al., 2004. The global decline of nonmarine mollusks. Bioscience, 54: 321-330.

Madoni, P., 1991. Role of Protozoans and Their Indicator Value in the Activated Sludge Process. In: Biological Approach to Sewage Teatment Process: Current Status and Perspectives, Madoni, P. (Ed.). Centro Luigi Bazzucchi, San Sisto, Perugia, Italy, pp: 21-27.

Margalef, R., 1969. Diversity and Stability: A Practical Proposal and a Model of Interdependence. In: Diversity and Stability in Ecological Systems, Woodwell, G.W. and H.H. Smith (Eds.). Brookhaven National Laboratory, Upton, New York, USA., pp: 25-37.
McCreesh, N., M. Arinaitwe, W. Arineitwe, E.M. Tukahebwa and M. Booth, 2014. Effect of water temperature and population density on the population dynamics of Schistosoma mansoni intermediate host snails. Parasites Vectors, 7: 1-10.

Salvado, H., M. Mas, S. Menendez and M.P. Gracia, 2001. Effects of shock loads of salt on protozoan communities of activated sludge. Acta Protozoologica, 40: 177-185.

Shannon, C.E. and W. Weaver, 1949. The Mathematical Theory of Communication. Vol. 2, University of Ilinois Press, Champaign, Illinois, USA., Pages: 117.

Smith, R., 2004. Current methods in aquatic science. Master Thesis, University of Waterloo, Canada.

Stewart, T.W. and J.E. Garcia, 2002. Environmental factors causing local variation density and biomass of the snail Leptoxis carinata, in Fishpond Creek, Virginia. Am. Midland Nat., 148: 172-181.

Thirupathaiah, M., C. Samatha and C. Sammaiah, 2012. Analysis of water quality using physico-chemical parameters in lower manair reservoir of Karimnagar district, Andhra Pradesh. Int. J. Environ. Sci., 3: 172-180.

Weiner, E.R., 2000. Application of Environmental Chemistry: A Practical Guide for Environmental Professionals. CRC Press, Boca Raton, Florida, USA., ISBN:9781566703543, Pages: 288.

Wetzel, R.G. and G.E. Likens, 2000. Limnological Analysis. 3rd Edn. Springer, New York, Pages: 429.

Wetzel, R.G., 2001. Limnology, Lake and River Ecosystems. 3rd Edn., Academic Press, Cambridge, Massachusetts, USA., ISBN: 9780127447605 , Pages: 1006.

Wurts, A.W. and R.M. Durborow, 1992. Interactions of $\mathrm{pH}$, Carbon Dioxide, Alkalinity and Hardness in Fish Ponds. SRAC Publication, USA. 